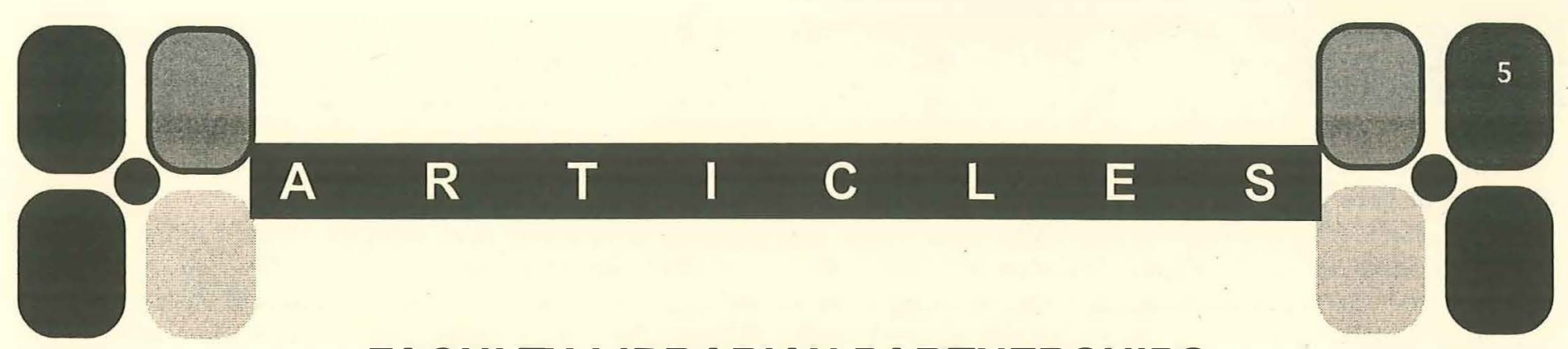

\title{
FACULTY-LIBRARIAN PARTNERSHIPS
}

\author{
by \\ Renée Nesbitt
}

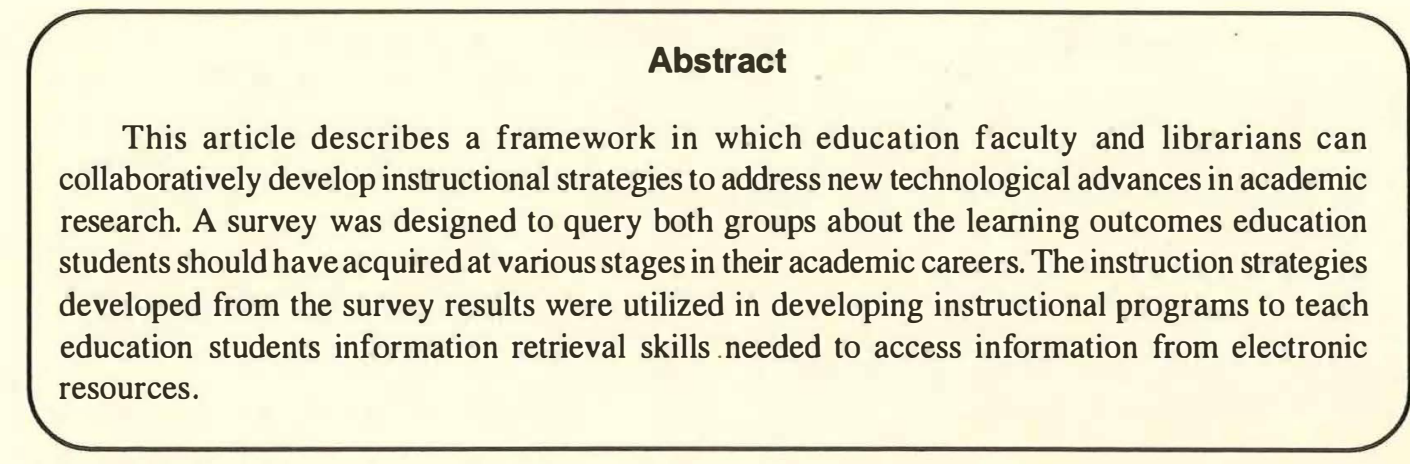

\section{INTRODUCTION}

Preparing future teachers to meet information technology and research challenges requires the collaborative development of instructional strategies by both education faculty and academic librarians. Education faculty and academic librarians have traditionally worked together to help students develop research skills. However, these partnerships generally centered around the development and implementation of a bibliographic instruction session. While bibliographic instruction has and will continue to play a major role in assisting students with their research needs, faculty and librarians continually strive to design, implement, and evaluate instructional strategies that address new technological advances in academic research.

Recently, a discussion series entitled The Academic Library in the Information Age: Changing Roles identified ways in which the academic community could seek new partnerships in the information age (Consortium for Educational Technology for University Systems, 1997). One area of focus for academic community partnerships was the changing role of academic librarians. In the discussion series, key role changes included partnering with discipline faculty and other specialists for delivery of information and instruction, designing instructional programs for information access, developing and implementing information policy, and serving as leaders and facilitators in introducing information technologies and ensuring their effective use.

The role changes outlined in the discussion series provide a platform on which collaborative development of instructional strategies between education faculty and librarians can be discussed. One approach to collaborative development would be to query faculty and librarians about the specific learning outcomes education students should demonstrate in the area of information retrieval. Utilization of this approach provides a framework for planning, implementing, and evaluating instructional strategies. The information obtained may be used to integrate new technological developments into existing instructional programs or to formulate strategies for developing new programs. In the following article, a survey that was designed to foster the collaborative development of instructional strategies between education faculty and librarians at a state university in California is presented.

\section{METHODOLOGY}

\section{Introduction}

In November 1995, an Affirmative Action Professional Development grant was awarded to develop the Electronic Information Survey. The purpose of the survey was to identify potential teaching strategies for integrating a CD-ROM Network and the use of two electronic classrooms into the library's instructional program. While the CD-ROM Network merely added more bibliographic databases to the existing collection of electronic information resources, the two electronic classrooms offered a new and interactive approach to providing library instruction. Previously, librarians utilized transparencies, handouts, and videotapes to teach students how to use electronic resources. Students would then utilize the terminals in the reference area to obtain actual experience in using a particular electronic resource. With the electronic classrooms, librarians were able to provide simultaneous instruction and utilization of a particular electronic resource. 
The goals were to formulate standards and policies for the utilization of library electronic resources, and to support the scholarly endeavor of the university community by identifying and providing access to electronic information resources. There were four objectives: (1) to develop criteria for decision-making in the utilization and implementation of electronic information technology, (2) to determine criteria for selecting electronic information resources to meet instructional needs, (3) to identify the electronic information needs of education students and faculty, and (4) to diagnose problems underlying and identify opportunities for addressing electronic information needs.

\section{Instrumentation}

The Electronic Information Survey was designed to query education faculty and librarians about the learning outcomes related to the information retrieval skills undergraduate education students should have acquired at different stages in their academic careers. The learning outcomes corresponded to instructional objectives identified in the Taxonomy of Educational Objectives (Bloom, 1956). The Taxonomy provides a classification of educational objectives that consists of a set of general and specific categories encompassing possible learning outcomes that might be expected from instruction. The classification scheme outlines a taxonomy for the cognitive, affective, and psychomotor domains. It was developed by psychologists, teachers, and test experts for use in curriculum development, teaching, and testing. The system is based on the assumption that learning outcomes can be best described in terms of changes in student performance, and is touted as being especially useful to educators who are attempting to state their instructional objectives in performance terms.

For this study, instructional objectives and learning outcomes were developed for the cognitive domain. The cognitive domain "includes those objectives which deal with the recall or recognition of knowledge and the development of intellectual abilities and skills" (Bloom, 1956). There are six major classes of objectives that are arranged in hierarchical order on the basis of the task complexity (knowledge, comprehension, application, analysis, synthesis, and evaluation). Knowledge, representing simple tasks, is defined as the remembering of previously learned material (e.g., defining an electronic resource such as the Educational Resources Information Center [ERIC] database). Comprehension is defined as the ability to understand the meaning of material (e.g., identifying specific parts of the bibliographic information found in ERIC). Application refers to the ability to use learned material in new and concrete situations (e.g., using bibliographic information found in a primary source to locate information a secondary source). Analysis refers to the ability to break down material into its component parts so that its organization structure may be understood (e.g., illustrating the steps of locating information in ERIC). Synthesis refers to the ability to put parts together to form a new whole (e.g., devising a relevant strategy to locate information in ERIC). Evaluation, representing the most complex task, refers to the ability to judge the value of material for a given purpose (e.g., judging the usefulness of a research strategy that will be used in locating information in ERIC). The instructional objective and four learning outcomes developed for each classification are presented below.

\section{Knowledge}

Instructional Objective

Learning Outcomes

Comprehension

Instructional Objective

Learming Outcomes
Knows common terms.

Identifies a definition of an electronic resource.

Describes information in an electronic resource.

List primary uses in an electronic resource.

Selects appropriate use of an electronic resource.
Understands procedure.

Identifies specific parts of the information in an electronic resource.

Identifies the order of steps to find information available in an electronic resource.

Distinguishes between correct and incorrect application of a research strategy.

Explains an appropriate use of the information in an electronic resource. 
Application

Instructional Objective

Learming Outcomes

Analysis

Instructional Objective

Learning Outcomes

Synthesis

Instructional Objective

Leaming Outcomes

Evaluation

Instructional Objective

Learning Outcomes
Demonstrates correct usage of procedures.

Distinguishes between plausible and implausible applications

of a research strategy.

Identifies errors in the application of a research strategy.

Uses information found in primary sources to locate relevant information in a secondary source.

Uses information found in secondary sources to locate relevant information in a primary source.

Establishes a logical sequence of steps when using a procedure and/or a source, moving from general to specific.

Illustrates the steps of a research strategy.

Identifies the relationship between parts of an electronic resource.

Identifies the relationship between primary and secondary sources.

Distinguishes between essential and unessential elements of an electronic resource.

Formulates a new scheme for organizing information.

Devises relevant strategies to locate information in an electronic resource.

Combines relevant parts of a research strategy.

Formulates a valid strategy for organizing information.

Explains the relationship between research strategies.

Judges the relationship between problem-solving strategies using external criteria.

Discriminates between plausible and implausible research strategies.

Judges usefulness of a research strategy.

Compares the relationships between research strategies.

Judges the organization of information located in an

electronic resource. 


\section{Data Collection and Analysis}

The survey was distributed to 85 faculty members, 74 education and 11 library faculty, during the spring 1996 quarter. The response rate was $38 \%$ for the total group, $30 \%$ for the education faculty, and $91 \%$ for the library faculty. Faculty were asked to identify which of the 24 learning outcomes education students should have acquired prior to entering college, prior to beginning their upper division course work, and prior to graduating from college. The same list of learning outcomes was used for each of the three identified stages in a student's academic career. To account for the recency effect, the order of the items was varied for each stage. Percentages were then computed and compared for each learning outcome.

\section{RESULTS}

Of interest to this study was the identification of learning outcomes to be utilized in designing, implementing, and evaluating instructional strategies related to information retrieval from electronic resources. The percentages of learning outcomes identified by education and library faculty were compared within each of the identified stages of a student's academic career. The learning outcome was targeted for integration into the instructional program if it was selected by more than 50 percent of either the education or library faculty. Those not meeting this criteria would be evaluated for inclusion in a future survey.

Table 1 identifies the learning outcomes education students should have acquired prior to entering college. Only one outcome was identified by both education and library faculty. Sixty-eight percent of the education and 70 percent of the library faculty selected a Synthesis outcome, Identifies the relationship between primary and secondary sources. The learning outcomes education faculty selected for inclusion in the instructional program were Application outcomes: Uses information found in primary sources to locate relevant information in a secondary source and Uses information found in secondary sources to locate relevant information in a primary sources, 59 and 55 percent respectively. The learning outcomes library faculty selected were Knowledge, Identifies a definition of an electronic resources (70\%) and List primary uses in an electronic resource (50\%); Analysis, Illustrates the steps of a research strategy (50\%) and Identifies the relationship between primary and secondary sources (50\%); and Synthesis, Formulates a valid strategy for organizing information (70\%).

Table 1

Percentages of Learning Outcomes Education Students Should Have Acquired Prior to Entering College

\begin{tabular}{|c|c|c|}
\hline $\begin{array}{c}\text { Education } \\
\text { Faculty } \\
(\%)\end{array}$ & $\begin{array}{c}\text { Librarians } \\
(\%)\end{array}$ & Learning Outcomes \\
\hline 41 & 70 & $\begin{array}{c}\text { Knowledge } \\
\text { Identifies a definition of an electronic resource. } \\
\text { List primary uses in an electronic resource. }\end{array}$ \\
\hline 59 & 50 & $\begin{array}{c}\text { Application } \\
\text { Uses information found in primary sources to locate } \\
\text { relevant information in a secondary source. }\end{array}$ \\
\hline 55 & 30 & $\begin{array}{c}\text { Uses information found in secondary sources to } \\
\text { locate relevant information in a primary source. }\end{array}$ \\
\hline 27 & 50 & $\begin{array}{c}\text { Analysis } \\
\text { Illustrates the steps of a research strategy. } \\
\text { Identifies the relationship between the primary and } \\
\text { secondary sources. }\end{array}$ \\
\hline 45 & 50 & $\begin{array}{c}\text { Synthesis } \\
\text { Formulates a valid strategy for organizing information. }\end{array}$ \\
\hline 68 & 70 &
\end{tabular}


Table 2 identifies the learning outcomes education students should have acquired prior to beginning their upper division course work. Fifteen of the 24 outcomes were selected by more than $50 \%$ of both education and library faculty. The learning outcomes selected by library faculty only were Comprehension, Distinguishes between correct and incorrect application of a research strategy (70\%); Analysis, Identifies the relationship between parts of an electronic resource (50\%) and Distinguishes between essential and unessential elements of an electronic resource (50\%); and Synthesis, Combines relevant parts of a research strategy (50\%). Education faculty did not select any other outcomes other than the 15 selected by both groups. As expected, all 24 of the learning outcomes were selected by more than 50 percent of both education and library faculty as outcomes education students should have acquired prior to graduating from college.

Table 2

Percentages of Learning Outcomes Education Students Should Have Acquired Prior to Beginning Upper Division Course Work

\begin{tabular}{|c|c|c|}
\hline $\begin{array}{l}\text { Education } \\
\text { Faculty } \\
(\%)\end{array}$ & $\begin{array}{c}\text { Librarians } \\
(\%)\end{array}$ & Learning Outcomes \\
\hline $\begin{array}{l}55 \\
50 \\
59 \\
68 \\
\end{array}$ & $\begin{array}{c}80 \\
90 \\
100 \\
80\end{array}$ & \begin{tabular}{l}
\multicolumn{1}{c}{ Knowledge } \\
Identifies a definition of an electronic resource. \\
Describes information in an electronic resource. \\
List primary uses in an electronic resource. \\
Selects appropriate use of an electronic resource.
\end{tabular} \\
\hline $\begin{array}{l}55 \\
64 \\
32 \\
50\end{array}$ & $\begin{array}{l}80 \\
70 \\
70 \\
60\end{array}$ & $\begin{array}{l}\text { Comprehension } \\
\text { Identifies specific parts of the information in an electronic resource. } \\
\text { Identifies the order of steps to find information available in an } \\
\text { electronic resource. } \\
\text { Distinguishes between correct and incorrect application of a research } \\
\text { strategy. } \\
\text { Explains an appropriate use of the information in an electronic } \\
\text { resource. }\end{array}$ \\
\hline 73 & 50 & $\begin{array}{l}\text { Application } \\
\text { Uses information found in primary sources to locate relevant } \\
\text { information in a secondary source. } \\
\text { Uses information found in secondary sources to locate relevant } \\
\text { information in a primary source. }\end{array}$ \\
\hline $\begin{array}{l}55 \\
41 \\
77 \\
41\end{array}$ & $\begin{array}{l}70 \\
50 \\
50 \\
50\end{array}$ & $\begin{array}{l}\text { Analysis } \\
\text { Illustrates the steps of a research strategy. } \\
\text { Identifies the relationship between parts of an electronic resource. } \\
\text { Identifies the relationship between the primary and secondary } \\
\text { sources. } \\
\text { Distinguishes between essential and unessential elements of an } \\
\text { electronic resource. }\end{array}$ \\
\hline $\begin{array}{l}68 \\
32 \\
68\end{array}$ & $\begin{array}{l}60 \\
50 \\
70\end{array}$ & $\begin{array}{l}\text { Synthesis } \\
\text { Devises relevant strategies to locate information in an electronic } \\
\text { resource. } \\
\text { Combines relevant parts of a research strategy. } \\
\text { Formulates a valid strategy for organizing information. }\end{array}$ \\
\hline $\begin{array}{l}36 \\
55\end{array}$ & $\begin{array}{l}50 \\
80\end{array}$ & $\begin{array}{l}\text { Evaluation } \\
\text { Discriminates between plausible and implausible research strategies. } \\
\text { Judges usefulness of a research strategy. }\end{array}$ \\
\hline
\end{tabular}




\section{Summary of the Results}

The survey was designed to provide academic departments and the library with information to be used in the collaborative development and/or evaluation of instructional programs. The focus of this study was the information retrieval skills education students should acquire during their academic careers. The procedure may be utilized by academic departments and libraries seeking to foster partnerships. It should be noted that interpretation of the information obtained is department-specific. While the results may not be generalized to other departments within the institution nor similar departments at other institutions, it is likely that the instructional programs developed will be of benefit to all students.

The information obtained for this study was used to provide a framework for integrating new technological advances in academic research into the library's instructional programs. The framework was centered around integrating the library's new electronic classrooms into the instructional program. One classroom contained 24 IBM-Compatible computer terminals and the other 18 Macintosh computers. Both classrooms provide access to the library's electronic resources, including the Internet. Library faculty received funding from campus grants to design and develop instructional programs for the electronic classroom environment. The following is a list of programs that were developed and implemented.

The University 100 workbook was designed to supplement the library component of the University Studies 100 course, a course designed to provide freshmen with academic and practical skills necessary to succeed in college. The workbook provides students with a walking tour of the library and information on the online catalog, periodical indexes, electronic resources, and advanced searching techniques.

\section{CONCLUSION}

The collaborative development of instructional strategies by education and library faculty is vital in preparing education students for the technological challenges they will encounter during their academic careers. This article presented a form of collaboration that was utilized at a state institution in California. The information obtained from the Electronic Information Survey provided a platform for discussion. Both education and library faculty received information that was used in planning, developing, and designing instructional sessions. This information included the technological advances in academic research that was incorporated into the education curriculum, the information retrieval skills students needed to complete research assignments, the research areas targeted for library instruction, and the strategies utilized in teaching education students how to retrieve the information needed to complete their assignments.

\section{Bibliography}

Bloom, B. S. (1956). Taxonomy of Educational Objectives: The Classification of Educational Goals. New York: Longmans, Green.

Bodi, S. (1992). Collaborating with Faculty in Teaching Critical Thinking: The Role of Librarians. Research Strategies, 10(2), 69-76.

Consortium for Educational Technology for University Systems (1997). The Academic Library in the Information Age: Changing Roles. Seal Beach, CA: The Trustees of the California State University.

Gronlund, N. E. (1991). How to Write and Use Instructional Objectives. New York: Macmillan.

Renée Nesbitt, Ph.D is Head of Reference Services at the John M. Pfau Library, California State University, San Bernardino, CA, 92407. Her Ph.D is in Educational Measurement and Statistics with a cognate in Information Science from the University of Iowa. She received the California State University, San Bernardino's Outstanding Librarian of the Year Award for 1996/97. 